\title{
MOLECULAR IDENTIFICATION AND MANAGEMENT OF RHIZOCTONIA FRAGARIAE THE PATHOGEN OF BLACK ROOT ROT OF STRAWBERRY PLANT
}

\author{
Brwa Azad Aziz, and Qasim Abdulla Marzani* \\ Dept. of Plant Protection, College of Agriculture, Salahadin University, Erbil, Kurdistan Region, Iraq - \\ qasim.marzani@gmail.com
}

Received: Dec. 2016 / Accepted: May 2017 / Published: Jun. 2017

https://doi.org/10.25271/2017.5.2.364

\begin{abstract}
:
Strawberry plants are susceptible to a large number of pests and diseases and this can affect the quality and yield value of the fruit. Black root rot is an important disease of strawberry caused by a complex of fungi including Rhizoctonia. The most recognizable species of Rhizoctonia are $R$. solani and $R$. fragariae which are multinucleate and binucleate species, respectively. This work is aimed to isolate, identify and control the strawberry root rot caused by $R$. fragariae. Infected strawberry samples were collected from Erbil, Slemani, Duhok and Garmiyan Provinces. The identification of isolated fungi was achieved by using traditional methods along with molecular methods using polymerase chain reaction (PCR). In the later method, specific primers were designed and used to identify Rhizoctonia species. Several disease management options, including biological by using two species of Trichoderma, and chemical methods using Pristine fungicide, were also investigated. Sampling of strawberry plants revealed that the disease is prevalent in Kurdistan region and the isolated fungi, $R$. solani, Rhizoctonia sp., and $R$. fragariae, were pathogens of the disease causing crown and root rot of strawberry. PCR amplification was confirmed the identification of the species of Rhizoctonia. The results of control methods revealed that the most effective treatments were achieved using the fungicide followed by the use of the combination of $T$. harzianum and $T$. viride.
\end{abstract}

KEYWORDS: Strawberry, Rhizoctonia fragariae, black root rot, PCR.

\section{INTRODUCTION}

Strawberry Fragaria $\times$ ananassa Duch., the red delicious fruit, is one of the youngest domesticated plants. Nowadays, this plant is cultivated worldwide for its fruit which is rich in high nutrients like vitamin $\mathrm{C}$, folate, and magnesium. It considered a very good antioxidant because it contains vitamin $\mathrm{C}$ and phenol compounds, and the potential role of strawberry consumption in human health and disease prevention is an active research area (Liston et al., 2014; Romandini et al., 2013; Giampieri et al., 2012). Strawberry is susceptible to a large number of pests and diseases, and this can affect on the quality and yield value of the fruit (Guerena and Born, 2007). The majority of these diseases are caused by such fungi as gray mold, powdery mildew, leaf spots, leaf blight, leaf scorch, black spot, fruit rot and anthracnose and a number of a soil borne diseases such as; Verticillium wilt, Fusarium wilt. The anthracnose, Black root rot, and crown rot are considered most common diseases of strawberry caused by Colletotrichum spp., Rhizoctonia spp., respectively. (Ullio, 2009, Ullio and Macarthur, 2011). Strawberry black root rot is an important disease that caused by a complex of fungi include two most recognizable species of Rhizoctonia which are $R$. solani (the multinucleate) and $R$. fragariae (the binucleate) (Botha et al., 2003). In older seedlings, the fungus is limited to cortical tissues and elongate tan to reddish-brown lesions develop which increase to girdle the stem and may be twisted or die (Agrios, 2005). Rhizoctonia spp, the pathogen of root rots of strawberry considered to be a major problem that threat commercial strawberry production worldwide and classified based on their cell nuclear condition into uninucleate, binucleate and multinucleate (Fang et al., 2013).
There are several disease management measures have been employed to manage plant diseases. These include crop rotation, pathogen-free seed, removal of plant debris, and fungicide treatments. More recently, there has been an international attempt to the use of eco-friendly methods for controlling pests and diseases. Application of potential harmful chemical sprays are viewed with displeasure in many countries. Among these sound methods is the use of biological agents such as the use of the antagonistic fungus Trichoderma which have attracted the attention of their multipronged action against a wide range of plant pathogens (Harman et al., 2004).

Strawberry is a newly cultivated crop in Iraq, and the improvement of strawberry production and business in the country is done with the aid of U.S. Government through the USAID-Inma agribusiness program and by permeation of Iraq's ministry of Agriculture in 2009. However, the cultivation of the crop is still restricted in small areas, research stations, house gardens and small farms (Bahram and Mohammed, 2006). Nevertheless, the importance of this crop is now increasing in Kurdistan, and few farms produce strawberry fruits and providing stocks to growers such as the one in Suse village/ Peramagron, in Slemani Province, comprising 10 greenhouses of strawberry which are growing a big red fruit variety Robygum continuously. Due to lack of any studies on strawberry diseases in Iraq in general and of Kurdistan region in particular, and due to growing demands on strawberry fruit and increase of new farms, this study was conducted and aimed to investigate the presence, identification and disease management options of black root rot pathogen.

\footnotetext{
* Corresponding author
} 


\section{MATERIALS AND METHODS}

\subsection{Sample Collection}

Sampling achieved during December 2013 to November 2014 in several areas where different strawberry cultivars grown in Kurdistan region farms, these included SusePeramagron (Slemani Province), Kalar (Garmiyan Province), Grdarasha, Ankawa, and Haji Omran (Erbil Province) and Duhok and Akre (Duhok province). Infected plant parts were collected in strawberry fields, kept in cool boxes during their way to the laboratories.

\subsection{Isolation}

Infected plant parts washed under tap water for up to one hour to remove any dirt and soil on the outstanding plant surface, then were cut into $2 \mathrm{~mm}$ pieces, and then sterilised superficially by $70 \%$ ethanol for 3 min, followed washing twice with sterilised distilled water to remove ethanol residues, then air-dried on sterilised filter paper before culturing on Petri plates containing fresh potato dextrose agar (PDA) medium and incubating at $25 \pm 2 \stackrel{\circ}{\mathrm{C}}$ for 2-5 days (Gilman, 1957 and Watanabe, 2010).

\subsection{Identification}

2.3.1 Traditional Identification: After the growth of fungal colonies, small pieces of young mycelium from edges of each colony was purified into new Petri plates containing PDA and incubated for one week. Fungal isolates were identified conventionally, using standard methods with the aid microscope and according to the taxonomic features described by (Watanabe, 2010).

2.3.2 Molecular Identification: Genomic DNA was extracted using DNA extraction Kit from Promega/ USA based on the modified procedure from the same company. The isolation of genomic DNA was made directly on the infected strawberry samples, and from the fungi isolated. The following protocol was used to extract DNA:

1. Fresh mycelium $(50 \mathrm{mg})$ of isolated fungi or the same amount of infected plant tissue were taken and frozen in liquid nitrogen and ground into a fine powder using a sterilized mortar and pestle.
2. Forty milligram of the powder was moved into $1.5 \mathrm{ml}$ of sterilized Eppendorf tube by sterilized spatula. Then $600 \mu 1$ of Lysis Solution were added into the same Eppendorf and vortexed 1-3 seconds for wetting the tissue of the plant or fungi.

3. The samples were incubated at $65^{\circ} \mathrm{C}$ for 15 minutes in a water bath.

4. $3 \mu 1$ of RNAse Solution were added to the samples and mixed by inverting the tubes $2-5$ times. The mixture where incubated at $37^{\circ} \mathrm{C}$ for 15 minutes in a water bath.

5. $200 \mu \mathrm{l}$ of Protein Precipitation solution, were added to the samples and vortexes in high speed for 20 seconds.

6. The samples were centrifuged for 3 minutes at $13000 \mathrm{rpm}$. A formation of tight pellet will precipitate of the proteins.

7. Then the supernatant that contain the DNA was carefully removed and delivered in to a new sterilized 1.5 Eppendorf tube, then $600 \mu \mathrm{l}$ of a room temperature isopropanol were added. The tube with the protein pellet was thrown away.

8. The solution was gently mixed by inversion until a thread like strand of DNA were formed a visible mass.

9. The samples in the new Eppendorf were centrifuged at $13000 \mathrm{rpm}$ for 1 minute at room temperature.

10. The supernatant were carefully removed. And then $600 \mu \mathrm{l}$ of room temperature of $70 \%$ ethanol were added and gently the tubes were inverted several times to wash the DNA. Then centrifuged at $13000 \mathrm{rpm}$ for 1 minute at room temperature.

11. The ethanol was separated carefully from the samples using micropipette considering not pipetting the loose pellet with the pipette, or otherwise the ethanol was purred carefully, leaving the pellet behind.

12. The tubes were placed upside down on a clean sterilized filter paper and were left until the pellet was air dried for 15 minutes.

13. $100 \mu \mathrm{l}$ of DNA rehydration solution were added for rehydrating the DNA by incubating the solution overnight at room temperature or at $4^{\circ} \mathrm{C}$.

14. DNA were stored in freezer at $\left(-20^{\circ} \mathrm{C}\right)$ until using.

For detection of associated fungi, species specific primers were used as shown in Table 1 were designed using primer 3 online programme (http://bioinfo.ut.ee/primer3-0.4.0/).

Table 1. Primers used for detection of the pathogen of strawberry black root rot

\begin{tabular}{|c|c|c|c|c|c|}
\hline $\begin{array}{c}\text { Primer } \\
\text { name }\end{array}$ & Direction & Target fungus & $\begin{array}{l}\mathrm{Tm} \\
{ }^{\circ} \mathrm{C}\end{array}$ & Primer sequence & Source \\
\hline Rf1 & Forward & $\begin{array}{l}\text { Rhizoctonia } \\
\text { fragariae }\end{array}$ & $\begin{array}{l}62 \\
{ }^{\circ} \mathrm{C}\end{array}$ & 5'-TGACATCTGCAAGACCTCCA-3' & \multirow{2}{*}{$\begin{array}{l}\text { Designed with Primer } 3 \text { (GenBank: accession } \\
\text { No. KP893156.1) (Zhong et al., 2016) }\end{array}$} \\
\hline Rf2 & Reverse & $\begin{array}{l}\text { Rhizoctonia } \\
\text { fragariae }\end{array}$ & $\begin{array}{l}62 \\
{ }^{\circ} \mathrm{C} \\
\end{array}$ & 5'-ACAACGGATCTCTTGGCTCT-3' & \\
\hline
\end{tabular}

DNA was amplified using thermocycler (PCR machine) in $25 \mu 1$ (reaction volume) in PCR tubes using PCR master mix from Promega / USA. The master mix was composed of:

- $12.5 \mu 1$ of $2 \mathrm{x}$ PCR master mix.

- $1 \mu$ l of each forward primer.

- $1 \mu 1$ of each reverse primer.

- $1 \mu 1$ of DNA template.

The volume was completed to $25 \mu 1$ by adding nuclease free water.

PCR was performed under the following conditions: initial preheat for $3 \mathrm{~min}$ at $95^{\circ} \mathrm{C}$, followed by 35 cycles at $95^{\circ} \mathrm{C}$ for 15 seconds, annealing temperature were ranged between $62^{\circ} \mathrm{C}$ for 30 seconds followed by final amplification step $72^{\circ} \mathrm{C}$ for $15 \mathrm{~min}$ (Xiao and Ligard, 2004).

Amplified DNA fragments were resolved on $1.5 \%$ Agarose gels (BIOMAX/Germany) for 60 minutes at 50 volts according to modified method of Sambrook and Russell
(2001). The gel was prepared with 1 x TAE buffer and Ethidium bromide was added to provide a final concentration of $0.5 \mu \mathrm{g} \mathrm{mL}$ ${ }^{1}$. Four microliters of each PCR product was loaded in to the gel well with $4 \mu \mathrm{L}$ of DNA size marker (100 bp ladder) (Promega, Madison, USA). A control sample (DNA-free sample) was also included in the gel electrophoreses. The gel was then visualised and using gel viewer (Mupid-2plas/Advance/Japan).

\subsection{Pathogenicity tests}

The pathogenic inoculum for $R$. fragariae was prepared according to the modified procedures of Xiangling et al., (2012) and Barbetti, (1989) as follows:

Fifty grams of millet seeds (Panicum miliaceum) were soaked in distilled water in $250 \mathrm{ml}$ flask for 12 hours, the excess water was then poured off and the seeds were autoclaved three consecutive times each at $121^{\circ} \mathrm{C}$ for 20 minutes. The autoclaved millet seeds 
in each flask were inoculated with 15 fungal plugs $(5 \mathrm{~mm})$ of each fungus taken from colonies grown on PDA. Flasks

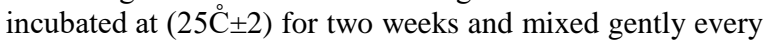
day to insure equal colonisation. Strawberry seedlings were transferred to the $13 \mathrm{~cm}$ diameter pots containing a mixture of sterilized soil and peatmoss (2:1) inoculated with the fungus grown on millet seeds at a rate of $0.5 \%(\mathrm{w} / \mathrm{w})$. The untreated control included growing seedlings in noninoculated soil. The strawberry, cv. Sweet Charley and cv. Rubygum, which were produced and maintained by planting the stocks in a greenhouse at $25-30^{\circ} \mathrm{C}$, were planted in the pots. All experiments were triplicated in Complete Randomized Design (CRD) with seven plants for each.

Rhizoctonia root rot disease was assessed on a 0 - 5 disease severity scale used by Fang et al., (2011) where: $0=$ root well developed, no discoloration; $1=<25 \%$ root discolored; $2=$ $\geq 25 \%, \quad<50 \%$ root discolored; $3=\geq 50 \%, \quad<75 \%$ root discolored; $4=\geq 75 \%$ root discolored; $5=$ all root discolored (rotted), plant death.

Crown disease caused by Rhizoctonia was assessed based on a $0-5$ disease severity scale, where: $0=$ no crown tissue discolored; $1=<25 \%$ crown tissue discolored; $2=\geq 25 \%$, $<50 \%$ crown tissue discolored; $3=\geq 50 \%,<75 \%$ crown tissue discolored; $4=\geq 75 \%$ crown tissue discolored; $5=$ all crown tissue discolored (rotted), plant dead.

Disease symptoms of each individual plant were then assessed by calculating the proportion of stem discoloration rated using 0-5 scale, as described by (Fernandez and Chen 2005) as described below:

Crowns was assessed based on stem discoloration on a 0-5 disease severity scale, where: 0 , no vascular tissue discolored; $1=<25 \%$ vascular tissue discolored; $2=\geq 25 \%$, $<50 \%$ vascular tissue discolored; $3=\geq 50 \%,<75 \%$ vascular tissue discolored; $4=\geq 75 \%$ vascular tissue discolored; $5=$ all vascular tissue discolored, plant dead.

$$
\text { DSI }=\frac{\sum(\text { class } \times \text { no. of plants in class })}{\text { Total no. of plants } \times(\text { no. of classes }-1)} \times 100
$$

\subsection{Disease management (Biological and Chemical)}

The pathogenic inoculum was prepared according to previous procedure described by (Barbetti, 1989). The colonizing of $T$. harzianum and $T$. viride was performed by mixing of $5 \mathrm{~g}$ of the commercial product of Trichoderma, Biocont-T (Ain AlSama, Saudi Arabia), with $5 \mathrm{~kg}$ of peatmoss, and incubated under greenhouse conditions at $25-27^{\circ} \mathrm{C}$ for two weeks. At the same time, seedlings of one-month old were brought and planted in $10 \mathrm{~cm}$ diameter pots. The experiment was contained five treatments in three replicates as shown in Table 2.

Table 2. Treatments used in control of strawberry black root rot caused by Rhizoctonia fragariae

\begin{tabular}{|c|c|}
\hline Treatment & Treatment descriptions \\
\hline 1 & $\begin{array}{l}\text { Inoculating } 15 \text { strawberry seedlings by } R \text {. } \\
\text { fragariae, colonized in millet seeds mixed with } \\
\text { colonized peatmoss by } T \text {. harzianum, in the same } \\
\text { rate that mentioned above. }\end{array}$ \\
\hline 2 & $\begin{array}{c}\text { Inoculating } 15 \text { strawberry seedlings by } R \text {. } \\
\text { fragariae colonized in millet seeds mixed with } \\
\text { colonized peatmoss with } T \text {. viride in the same rate. }\end{array}$ \\
\hline 3 & $\begin{array}{l}\text { Inoculating } 15 \text { strawberry seedlings with a millet } \\
\text { seeds colonized by } R \text {. fragariae mix with a } \\
\text { combination of equal amount of peatmoss that } \\
\text { colonized with } T \text {. harzianum and } T \text {. viride, in the } \\
\text { same rate. }\end{array}$ \\
\hline 4 & $\begin{array}{l}\text { Dipping the root of strawberry seedlings in } \\
\text { Pristine fungicide before planting in peatmoss } \\
\text { inoculated with colonized millet seeds by } R \text {. } \\
\text { fragariae.(dissolving } 2 \mathrm{~g} \text { of fungicide in } 250 \mathrm{ml} \\
\text { S.D.W) }\end{array}$ \\
\hline
\end{tabular}

Fifteen strawberry seedlings inoculated with $R$. fragariae inoculum only by mixing colonized millet seeds with sterilized petmous only in a rate of $0.5 \% \mathrm{w} / \mathrm{w}$ (control).

\section{RESULTS}

\subsection{Isolation and microscopic dentification}

From the infected strawberry plant samples with visible symptoms brought to the laboratory from different locations, three species of Rhizoctonia were isolated from crown and roots of strawberry samples. Species of Rhizoctonia were isolated from all locations except Kalar (Garmian Province). The direct isolation of pathogens from infected strawberry plants was achieved with the aid of cultural characteristics and microscopic features demonstrated that the most important suspected fungi were, Rhizoctonia fragariae and Rhizoctonia solani.

\subsection{Molecular identification using PCR}

To confirm the identification of Rhizoctonia spp., which isolated from discoloured crown and rotten roots, specific primers that detect the species of Rhizoctonia fragariae were used. Based on species- specific primers, the results revealed that four out of 8 samples screened were Binuclate $R$. fragariae. These include sample 4, 5, 6 and 8 with the band sizes of 250 bp (Figure 1). However, samples 2 (a suspected fungus described as a Rhizoctonia sp. microscopically), sample 3 (Rhizoctonia sp. isolate SS identified microscopically), and sample 7 (unknown species of Rhizoctonia having knobs and producing sclerotia from Suse) were not detected by the primers confirming that they are not $F$. fragariae.

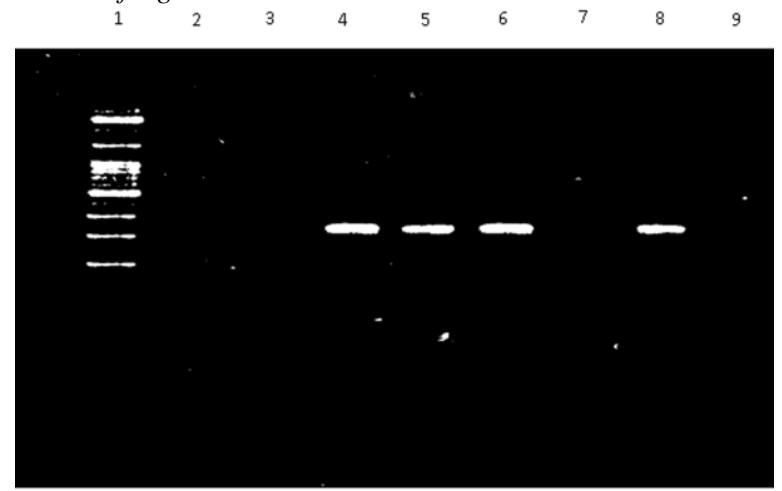

Figure 1. detection of Rhizoctonia species using polymerase chain reaction with specific primers. (Where $1=100 \mathrm{bp}$ ladder, $2=$ suspected isolate from Grdarasha, $3=$ Rhizoctonia sp. (SS1) identified microscopically, $4=R$. fragariae isolated from root/ Suse, $5=R$. fragariae isolated from crown/ Suse, $6=R$. fragariae isolated from /Hajiomran, $7=$ unknown have knob + sclerotia $/$ Suse, $8=R$. fragariae isolated from / Grdarasha, $9=$ no template control. The conventional identification for samples 2, 3, and 7 was previously revealed that they are Rhizoctonia sp. but the DNA-based identification confirmed they are not $R$. fragariae).

\subsection{Pathogenicity tests of Rhizoctonia species}

The results of pathogenicity tests for crown rot, root rot, and vascular tissues in Table 3 demonstrate that the highest and considerable pathogenic isolate for crown rot was $R$. solani (isolate SS2) with disease severity of $42.8 \%$ compared to the lowest one for $R$. solani (isolate Ho) with disease severity of $26.7 \%$, and the virulence of Grdarasha isolate $(\mathrm{Gr})$ and $R$. fragariae (SS1) were similar.

For root rot infections, the highest infection was by $R$. solani (SS2) with disease severity of $39.7 \%$ and the lowest one was also 
$R$. solani (Ho) with $28.8 \%$ disease severities. The highest severity of $40.5 \%$ of vascular infection was caused by $R$. solani (SS2).

Table 3. Pathogenicity tests of isolates of Rhizoctonia species

\begin{tabular}{lccc}
\hline & \multicolumn{3}{c}{ Disease Severity Index } \\
\cline { 2 - 4 } Treatment & Root rot & Crown rot & $\begin{array}{c}\text { Crown } \\
\text { Vascular } \\
\text { tissue }\end{array}$ \\
\hline $\begin{array}{l}\text { R. solani isolate } \\
\text { (Gr.) }\end{array}$ & 33.6 & 33.7 & 32.6 \\
\hline $\begin{array}{l}R . \text { solani isolate } \\
\text { (Ho.) }\end{array}$ & 28.8 & 26.7 & 21.7 \\
\hline $\begin{array}{l}R . \text { solani isolate } \\
\text { (SS2) }\end{array}$ & 39.7 & 42.8 & 40.5 \\
\hline $\begin{array}{l}\text { R. fragariae } \\
\text { isolate (SS1) }\end{array}$ & 35.8 & 40.8 & 28.7 \\
\hline Untreated & & & \\
\hline control & 0 & 0.61 & 0.85 \\
\hline \begin{tabular}{l} 
LSD (0.05) \\
\hline
\end{tabular} & 0.80 & & \\
\hline
\end{tabular}

The symptoms of R. solani (Gr.) as shown in (figure $2 \mathrm{~A}$ ) was slightly rotten root with dark crown and pinkish vascular tissues. The symptoms appeared due to the infection by $R$. solani isolate ( $\mathrm{Ho}$ ) as in (figure $2 \mathrm{~B}$ ) appeared as root discoloration with dark crown and vascular tissues. A reduction in root growth was occurred by $R$. fragariae (figure $2 \mathrm{C}$ ), the infected plants have brown to dark crowns and slightly browning of vascular tissues. In $R$. solani isolate (SS2) in (figure 2 D) infected roots was completely rotted and deteriorated with darkness crown and brown streaking of vascular tissues.
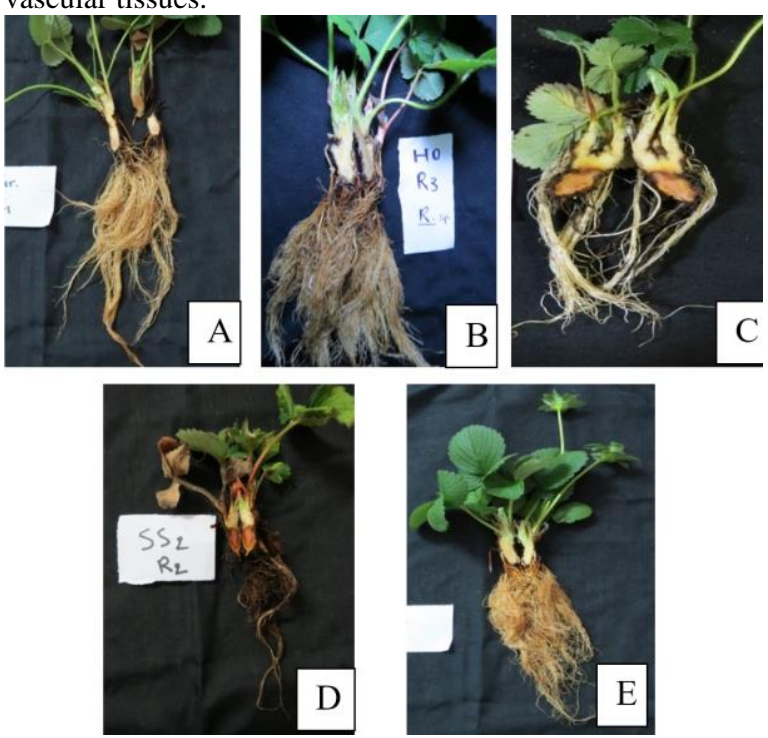

Figure 2. Symptoms caused by Rhizoctonia spp. Isolates, where: A$R$. solani (Gr) B- $R$. solani (Ho) C- $R$. fragariae (SS1) D- $R$. solani $(\mathrm{SS} 2)$ and E- untreated control.

\subsection{Control of R. fragariae}

A reduction of disease severity was occurred on strawberry plants when both species of the bioagent, T. harzianum and $T$. viride are applied, whether applied together or when used as individual treatments (Table 4). T. harzianum reduced the severity of wilted plants to $18.25 \%$. However, $T$. viride was found to be more efficient when decreased wilting of the plants to $8.25 \%$ only. The effect of the combination of both $T$. harzianum and $T$. viridi minimized infected plants to $16.5 \%$ only. The most effective treatment was the use of the fungicide, Pristine, when reduced plant wilting to $3.25 \%$ only.

Table 4. The efficacy of different bio and chemical treatments on the severity of black root rot caused by $R$. fragariae

\begin{tabular}{ccccc}
\hline & \multicolumn{4}{c}{ \% Disease Severity Index } \\
\cline { 2 - 5 } Treatment & Root rot & $\begin{array}{c}\text { Crown } \\
\text { rot }\end{array}$ & $\begin{array}{c}\text { Browning } \\
\text { of crown } \\
\text { vascular } \\
\text { tissue }\end{array}$ & $\begin{array}{c}\text { Plant } \\
\text { wilting }\end{array}$ \\
\hline $\begin{array}{c}\text { T. harzianum } \\
+ \text { T. viridi }\end{array}$ & 24 & 21 & 16 & 16.5 \\
\hline T. viridi & 35 & 30 & 19.6 & 8.25 \\
\hline $\begin{array}{c}\text { T. harzianum } \\
\text { Fungicide } \\
\text { Pristine) }\end{array}$ & 37.6 & 39 & 18 & 18.25 \\
\hline $\begin{array}{c}\text { Untreated } \\
\text { control }\end{array}$ & 39.3 & 60 & 41 & 30 \\
\hline LSD 0.05 & 35 & 32.25 & 42.75 & 9.25 \\
\hline
\end{tabular}

\section{DISCUSSIONS}

The results of this study revealed that black root rot disease of strawberry is widespread in the Provinces of Southern region of Kurdistan. The major pathogen of the disease found to be three species of Rhizoctonia. Previous works by Fang et al., (2011) also confirmed that Rhizoctonia species are important pathogens associated with strawberry crown and root disease. In the current study, further confirmation of the pathogen was achieved by using PCR with specific primers was also proved the identification. This technique helps quick and accurate pathogen diagnosis among several pathogens associated with root rots. Previous work also concluded the identification using molecular methods and detected some 96 isolates of binuclaete $R$. fragariae from diseased strawberry plants in Western Australia characterized by their nuclear condition, virulence, genetic diversity and polygenetic status (Fang et al., 2013). Results were also confirmed by Botha et al., (2003) that Rhizoctonia spp. and anastomosis groups were isolated from diseased strawberry plants in Western Cape Province of South Africa, both binucleate and multinucleate types were recovered from diseased roots and identified as $R$. fragariae and $R$. solani, respectively.

The results of pathogenicity of Rhizoctonia isolates were investigated and found that $R$. solani isolates were most virulent causing severe disease symptoms on strawberry plants. Similar results obtained by Botha et al., (2003) in South Africa and found that $R$. solani isolates were the most virulent species causing sever stunting of plants. Nevertheless, $R$. fragariae sometimes also cause stunting in plant growth with small pale spreading lesions on the infected roots.

Two methods of control were evaluated to limit black root rot disease of strawberry. Although the use of the fungicide, Pristine, was the most effective method in minimizing the disease but the biological control using two species of the bioagent fungus, $T$. harzianum and $T$. viridi, was also decreased the disease significantly. In a similar study to control Rhizoctonia carried out by Zhang et al., (2009) in which they used Boscalid fungicide (one of active ingredients of Pristine) to control isolates of $R$. solani, they stated that the fungicide's efficiency was up to $58 \%$ in disease control. The greatest inhibition of $R$. fragariae pathogen on the symptomatic strawberry plants achieved when both Trichoderma species are combined in one treatment. Thus, the severity of crown and root rot and browning of vascular crown resulted were $24 \%, 21 \%$ and $16 \%$, respectively. Aly and 
Manal (2009) also confirmed the efficiency of $T$. viride against $R$. solani agents in greenhouse. Trichoderma spp. has been widely used as antagonistic fungal agents against several pests as well as plant growth enhancers (Verma et al., 2007). Disease severity of $R$. solani in daughter strawberry plants was reduced by $18-46 \%$ in treated nursery's plots with T. harzianum. Furthermore, more isolates of Trichoderma sp. antagonistic to $R$. solani were found in infested field by the pathogen compared to non-infested one (Elad et al., 1981). Several modes of action have been proposed to explain the biocontrol of plant pathogens by Trichoderma, these include production of antibiotic and cell wall degrading enzymes, competition for key nutrients, parasitism, stimulation of plant defence mechanisms and combination of those possibilities (Harman, 2006). Trichoderma spp. generally grows in its natural habit on plant root surface and therefore it controls root diseases in particular (Monte, 2001).

It can be concluded that strawberry plants are vulnerable to root rots caused by different species of Rhizoctonia. From these species, $R$. fragariae and $R$. solani are attacking strawberry plants widely. The results of this study revealed that early detection of root rot disease is possible with the use of PCR techniques and therefore, the disease could be managed properly. It could also be concluded from the results of this research that the use of systemic fungicides, such as the use of Pristine (a combination of Pyraclostrobin and Boscalid), is one of the best control methods to limit the losses due to root rots. However, the application of biological control, although is not as effective as fungicides, but could be a safer alternative method to chemicals.

\section{REFERENCES}

Agrios, G.N. 2004. Plant pathology. Academic Press. New York, USA. $922 \mathrm{pp}$.

Aly, M. and Manal, Y. H. 2009. Vesicular-arbuscular mycorrhiza and Trichoderma viride as deterrents against soil-borne root rot disease of sugar beet. Sugar Technology 11: 387391

Botha, A., Denman, S., Lamprecht, S., Mazzola, M. and Crous, P. 2003. Characterisation and pathogenicity of Rhizoctonia isolates associated with black root rot of strawberries in the Western Cape Province, South Africa. Australasian plant pathology. 32: 195-201.

Barbetti, M. 1989. Response of subterranean clover cultivars to Phytophthora clandestina. Phytophylactica. 21: 65-67.

Bahram K.H.and Mohammed, S. M. T. 2006. A comparison between five varieties of strawberry to determine the best fitted one to location of Grdarasha and Ankawa / Erbil. Kirkuk university journal scientific studies. 1 (1): 76-89

Elad, Y., Chet, I. and Henis, Y. 1981. Biological control of Rhizoctonia solani in strawberry fields byTrichoderma harzianum. Plant and Soil. 60: 245-254.

Fang, X., Flinnegan, P. M. and Barbetti, M. J. 2013. Wide variation in virulence and genetic diversity of binucleate Rhizoctonia isolates associated with root rot of strawberry in Western Australia. Plos One 8 (2) : 1-14.

Fang, X., Phillips, D., Li, H., Sivasithamparam, K. and Barbetti, M. 2011. Severity of crown and root diseases of strawberry and associated fungal and oomycete pathogens in Western Australia. Australasian plant pathology. 40: 109-119.

Fernandez, M.R. and Chen, Y. 2005. Pathogenicity of Fusarium species on different plant parts of spring wheat under controlled conditions. Plant Disease 89: 164-169.

Giampieri, F., Tulipani, S., Alvarez-Swarez, J. M., Quiles, J. L., Mezzetti, B. and Battino, M. 2012. The strawberry: composition, nutritional quality, and impact on human health. Nutrition. 28: 9-19.

Gilman, J. C. A. 1957. Manual of Soil Fungi.. Iowa State College Press. Ames, Iowa.

Guerena, M. and Born, H. 2007. Strawberries: organic production. Available by ATTRA-NCAT http://attra. ncat. org/attrapub/PDF/strawberry. pdf (verified March 25, 2011).
Harman, G. 2006. Overview of mechanisms and uses of Trichoderma spp. Phytopathology. 96: 90-94.

Harman, G. E., Howell, C. R., Viterbo, A., Chet, I. and Lorito, M. 2004. Trichoderma species - opportunistic, avirulent plant symbionts. Nature reviews microbiology, 2: 43-56.

Liston, A., Cronn, R. and Ashman, T. L. 2014. Fragaria: A genus with deep historical roots and ripe for evolutionary and ecological insights. American Journal of Botany. 101: 1686-1699.

Monte, E. 2001. Understanding Trichoderma: between biotechnology and microbial ecology. International Microbiology, 4: 1-4.

Romandini S., L. Mazzoni, F. Giampieri, S. Tulipani, M. Gasparrini, N. Locorotondo, B. Mezzetti, and S. Bompadre. 2013. Effects of an acute strawberry (Fragaria $\times$ ananassa) consumption on the plasma antioxidant status of healthy subjects. Journal of Berry Research 3: 169-179.

Sambrook, J. and Russel, D. W. 2001. Detection of DNA in agarose gels. Molecular Cloning: A Laboratory Manual. $2^{\text {nd }}$ edition, Cold spring harbor laboratory press, $1546 \mathrm{pp}$.

Ullio, L. 2009. Common diseases of strawberries. www. dpi. nsw.gov.au/ Primefacts892. Industry and Investment NSW. 1832-6668.

Ullio, L. and Macarthur, E. 2011. Strawberry disease control guide. Agrecultural fact $\mathrm{H} 3.3 .1$ third edition. 0725-7759

Verma, M., Brar, S. K., Tyagi, R., Surampalli, R. and Valero, J. 2007. Antagonistic fungi, Trichoderma spp.: panoply of biological control. Biochemical Engineering Journal. 37: 1-20.

Watanabe, T. 2010. Pictorial atlas of soil and seed fungi: morphologies of cultured fungi and key to species, CRC press.ISBN: 978-14398-3.

Xiangling, F., Phillips, D., Verheyen, G., Hua, L., Sivasithamparam, K. and Barbetti, M. J. 2012. Yields and resistance of strawberry cultivars to crown and root diseases in the field, and cultivar responses to pathogens under controlled environment conditions. Phytopathologia Mediterranea. 51: 69-84.

Xiao, C. L., and Ligard, D. E. 2004. Genetic and pathogenic analyses of Collectotrichum gloeosporioides isolates from strawberry and non-cultivated hosts. Phytopathology, 94 (5): 446 - 453.

Zhang, C., Liu, Y., Ma, X., Feng, Z. and Ma, Z. 2009. Characterization of sensitivity of Rhizoctonia solani, causing rice sheath blight, to mepronil and boscalid. Crop Protection.28: 381-386.

Zhong, S., Xu, J. M., Yin, S. L., \& Zhang, G. Z. (2016). First Report of Root Rot on Strawberry Caused by Binucleate Rhizoctonia AG-A in China. Plant Disease, 100 (1): 225. 
ناسينهوهى كهرديلهيى و كوّنتروّلكردنى رايزوكتونيا فراكَاريى Rhizoctonia fragatiae هوّكارى نه خوّشى رهشهَهنينى رِّى رِوهكى شلك

\section{كورتيا ليّكولينى:}

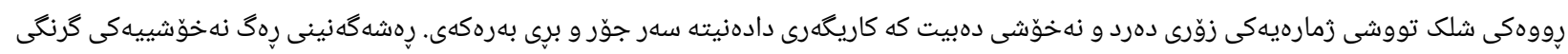

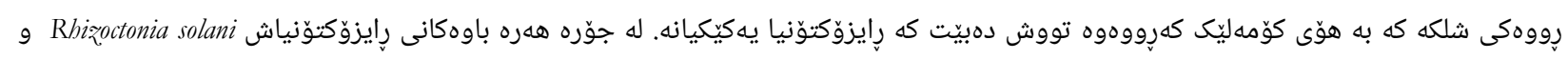
Rhizoctonia fragariae

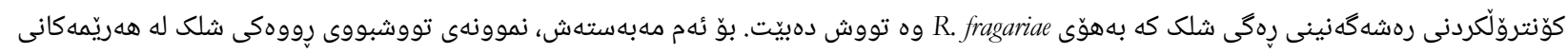

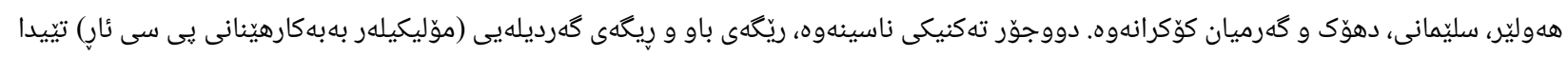

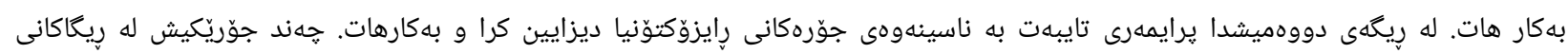

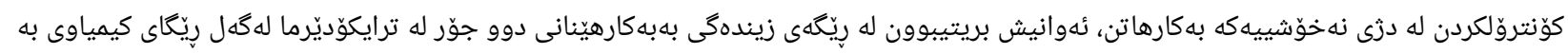

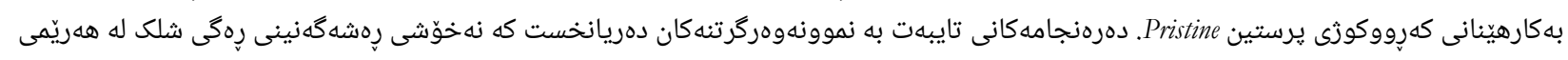

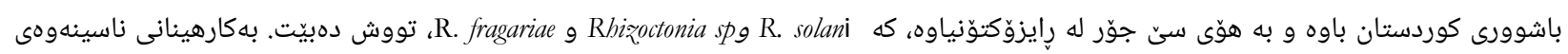

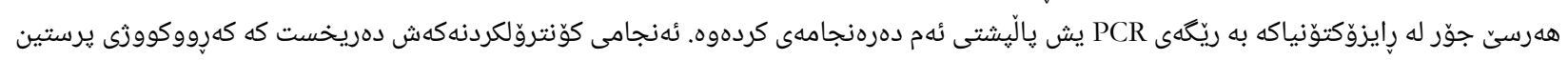

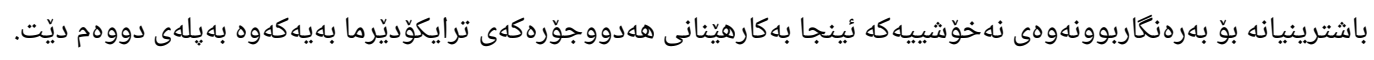

التشخيص الجزيئي و مكافحة رايزوكتونيا فراكاري Rhizoctonia fragariae المسبب لمرض تعفن الجذر الاسود لنبات الشليك

\section{خلاصة البحث:}

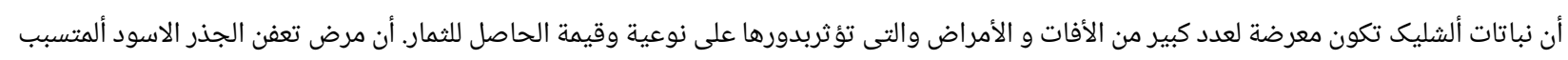

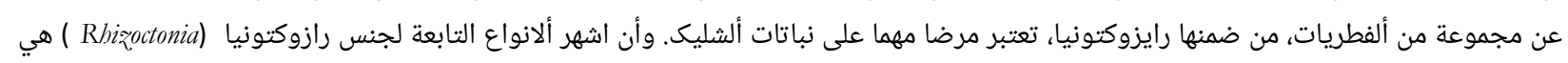

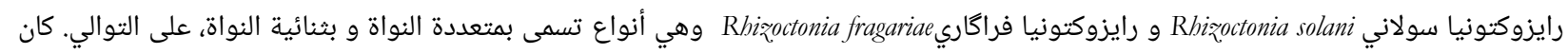

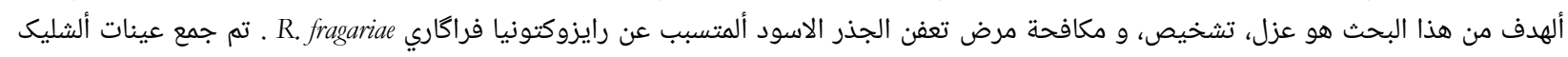

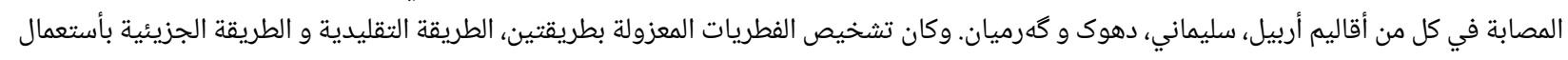

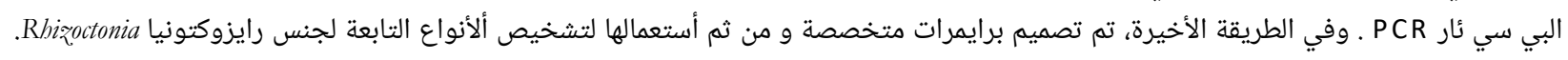

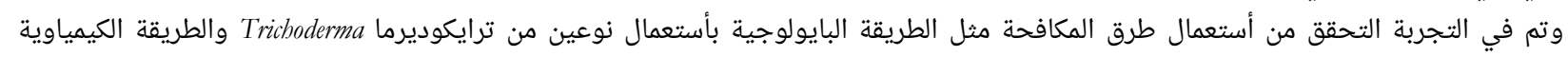

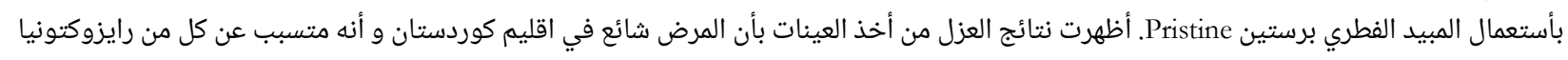

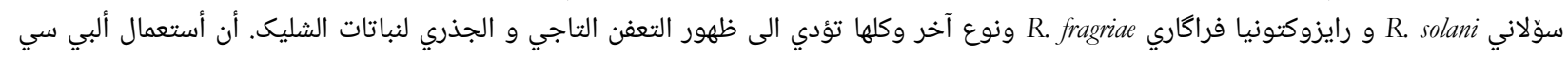

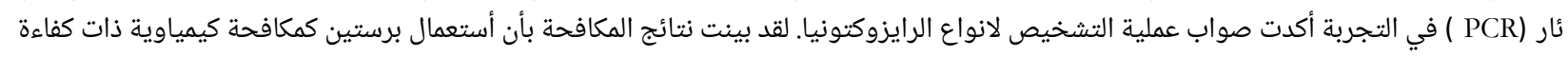

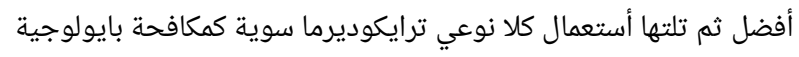

